\title{
Effects of Recombinant Human Insulin-Like Growth Factor I Administration on Spontaneous and Growth Hormone (GH)-Releasing Hormone-Stimulated GH Secretion in Anorexia Nervosa*
}

\author{
LAURA GIANOTTI, ANGELA I. PINCELLI, MASSIMO SCACCHI, MIMMA ROLLA, \\ DEANNA BELLITTI, EMANUELA ARVAT, FABIO LANFRANCO, \\ ANTONIO TORSELLO, EZIO GHIGO, FRANCO CAVAGNINI, AND \\ EUGENIO E. MÜLLER \\ Division of Endocrinology (L.G., E.A., F.L., E.G.), Department of Internal Medicine, University of \\ Turin, 10126 Turin; Second Chair of Endocrinology (A.I.P., M.S., F.C.), University of Milan, San Luca \\ Hospital, 20149 Milano; Unit of Adolescentology (M.R., D.B.), University of Pisa, 56100 Pisa; and \\ Department of Pharmacology (A.T., E.E.M.), University of Milan, 20129 Milano, Italy
}

\begin{abstract}
Exaggerated GH and reduced insulin-like growth factor I (IGF-I) levels are common features in anorexia nervosa (AN). A reduction of the negative IGF-I feedback could account, in part, for GH hypersecretion. To ascertain this, we studied the effects of recombinant human (rh)IGF-I on spontaneous and GH-releasing hormone (GHRH)stimulated $\mathrm{GH}$ secretion in nine women with AN [body mass index, $14.1 \pm 0.6 \mathrm{~kg} / \mathrm{m}^{2}$ ] and in weight matched controls (normal weight). Mean basal $\mathrm{GH}$ concentrations (mGHc) and $\mathrm{GHRH}(2.0 \mu \mathrm{g} / \mathrm{kg}$, iv) stimulation were significantly higher in AN. rhIGF-I administration $(20 \mu \mathrm{g} / \mathrm{kg}, \mathrm{sc})$ significantly reduced $\mathrm{mGHc}$ in AN $(P<0.01)$, but not normal weight, and inhibited peak GH response to $\mathrm{GHRH}$ in both
\end{abstract}

groups; mGHc and peak $\mathrm{GH}$, however, persisted at a significantly higher level in AN. Insulin, glucose, and IGFBP-1 basal levels were similar in both groups. rhIGF-I inhibited insulin in AN, whereas glucose remained unaffected in both groups. IGFBP-1 increased in both groups $(P<0.05)$, with significantly higher levels in AN. IGFBP-3 was under basal conditions at a lower level in AN $(P<0.05)$ and remained unaffected by rhIGF-I. This study demonstrates that a low rhIGF-I dose inhibits, but does not normalize, spontaneous and $\mathrm{GHRH}$-stimulated $\mathrm{GH}$ secretion in $\mathrm{AN}$, pointing also to the existence of a defective hypothalamic control of $\mathrm{GH}$ release. Moreover, the increased IGFBP-1 levels might curtail the negative IGF-I feedback in AN. (J Clin Endocrinol Metab 85: 2805-2809, 2000)
$\mathrm{I}^{\mathrm{s}}$

NSULIN-LIKE growth factor (IGF)-I exerts an inhibitory feedback action on GH secretion both in animals and in humans (1-13). The negative IGF-I feedback may occur directly at the pituitary, through activation of the IGF-I receptor, leading to inhibition of GH synthesis and release (1-5). Alternatively, indirect central nervous system-mediated mechanisms, such as stimulation of hypothalamic SRIF and/or inhibition of GHreleasing hormone $(\mathrm{GHRH})$-secreting neurons, have been hypothesized $(1,11,14,15)$, though it has been suggested that IGF-II coadministration is also needed to allow an inhibitory effect on somatotroph secretion (16).

In anorexia nervosa (AN), as well as in malnutrition and catabolic states, low IGF-I levels are generally coupled to GH hypersecretion (17-22), denoting the existence of peripheral GH resistance $(20,23)$. GH hypersecretion in AN would rest on the reduction of the negative IGF-I feedback mechanism $(19,21-23)$, as also implied by evidence that recombinant

Received December 8, 1999. Revision received April 21, 2000. Accepted May 12, 2000.

Address correspondence and requests for reprints to: Prof. E. E. Muller, Department of Pharmacology, University of Milan, Via Vanvitelli 32, Milano, Italy. E-mail: eugenio.muller@unimi.it.

* This study was supported by Pharmacia \& Upjohn, Inc., Europeptides, Consiglio Nazionale delle Ricerche (Grant 98.03040.CT04, Rome, Italy), MURST (Grant 9706151106, Rome, Italy), and the SMEM Foundation. human (rh)IGF-I, administered to subjects with GH hypersecretion, inhibits the secretion of GH $(7,8,10,24,25)$.

Alternatively, GH hypersecretion in AN could be caused by primary alteration in the neural control of somatotroph function $(17,18,22,26-28)$. In fact, GH secretion in AN is rather refractory to the inhibition exerted by cholinergic antagonists $(17,18)$, as well as to the stimulation by cholinergic agonists or $\beta$ adrenergic antagonists $(27,28)$, effects which are allegedly attributable to modulation of hypothalamic SRIF release $(29,30)$.

The aim of the present study was to substantiate the view that GH hypersecretion in AN occurs because of the lack of adequate IGF-I feedback action. Were this the case, patients with AN should present with normalization of both spontaneous and GHRH-stimulated GH secretion after pretreatment with rhIGF-I.

\section{Subjects and Methods}

\section{Drugs}

Vials containing $1000 \mu \mathrm{g}$ liophylized rhIGF-I were kindly provided by Pharmacia \& Upjohn, Inc. (Stockholm, Sweden). Vials containing $50 \mu \mathrm{g}$ GHRH-29 were kindly provided by Serono Laboratories, Inc. (Rome, Italy).

\section{Study protocols}

Nine female patients with AN (age, mean \pm SEM, $24.0 \pm 1.4$ yr; body mass index, $14.1 \pm 0.6 \mathrm{~kg} / \mathrm{m}^{2}$ ) took part in the study. Clinical and 
hormonal details of the patients are reported in Table 1. All AN patients were in the acute phase of the illness and met the diagnostic criteria for AN according to Diagnostic and Statistical Manual of Mental Disorders IV (31). They were not under treatment with psychoactive drugs.

The results in AN were compared with those obtained in eight normal young women (NW; age, $28.3 \pm 1.2 \mathrm{yr}$; body mass index, $20.1 \pm 0.5$ $\mathrm{kg} / \mathrm{m}^{2}$ ), studied in their early follicular phase (13).

All subjects gave an informed consent to participate in the study, which had been approved by an independent ethical committee.

All subjects underwent the following tests at least 3 days apart: 1) placebo (sc administration of isotonic saline at $0 \mathrm{~min}$ ); 2) rhIGF-I administration $(20 \mu \mathrm{g} / \mathrm{kg}$, sc at $0 \mathrm{~min}) ; 3)$ placebo $+\mathrm{GHRH}(2.0 \mu \mathrm{g} / \mathrm{kg}$, iv at $+180 \mathrm{~min}$ ); and 4 ) rhIGF-I+GHRH.

The tests were begun at $0830-0900 \mathrm{~h}$, after an overnight fast and 30 min after an indwelling catheter had been placed into an antecubital vein of the forearm, kept patent by slow infusion of isotonic saline.

Blood samples were drawn basally at $0 \mathrm{~min}$ and then every $15 \mathrm{~min}$ up to $+300 \mathrm{~min}$

Serum GH levels were measured at each time interval in all sessions. Serum IGF-I, serum insulin, and plasma glucose levels were measured basally and then every $30 \mathrm{~min}$, up to $+300 \mathrm{~min}$, in all sessions. Serum IGFBP-1 and IGFBP-3 levels were measured basally and at $300 \mathrm{~min}$ in sessions 1 and 2 .

Serum GH levels ( $\mu \mathrm{g} / \mathrm{L})$ were measured in duplicate by immunoradiometric assay (hGH-CTK IRMA, Sorin Biomedica, Saluggia, Italy). The sensitivity of the assay was $0.15 \mu \mathrm{g} / \mathrm{L}$. The inter- and intraassay coefficients of variation were $2.9-4.5 \%$ and $2.4-4.0 \%$, respectively.

Serum IGF-I levels $(\mu \mathrm{g} / \mathrm{L})$ were measured in duplicate by RIA (Nichols Institute Diagnostics, San Juan Capistrano, CA). All samples were extracted with acid-ethanol to avoid interference by binding proteins. The sensitivity of the assay was $0.1 \mu \mathrm{g} / \mathrm{L}$. The inter- and intraassay coefficients of variation were $10.1-15.7 \%$ and $7.6-15.5 \%$, respectively.

Serum insulin levels $(\mathrm{mU} / \mathrm{L})$ were measured in duplicate by immunoradiometric assays (Sorin Biomedica). The sensitivity of the assay was $2.5 \pm 0.3 \mathrm{mU} / \mathrm{L}$. Inter- and intraassay coefficients of variation were between 6.2 and $10.8 \%$ and between 5.5 and $10.6 \%$, respectively.

Plasma glucose levels $(\mathrm{mg} / \mathrm{dL})$ were measured by a glucose-oxidase colorimetric method (GLUCOFIX, Menarini Diagnostics, Firenze, Italy).

Serum IGFBP-1 levels $(\mathrm{ng} / \mathrm{mL})$ were measured in duplicate by immunoradiometric assay provided by Diagnostics Systems Laboratories, Inc., Webster, TX. The sensitivity of the assay was $0.33 \mathrm{ng} / \mathrm{mL}$. The interand intraassay coefficients of variation were between 3.5 and $6.0 \%$ and between 2.7 and $5.2 \%$, respectively.

Serum IGFBP-3 $(\mu \mathrm{g} / \mathrm{mL})$ were measured in duplicate by RIA provided by Nichols Institute Diagnostics. The sensitivity of the assay was $0.0625 \mu \mathrm{g} / \mathrm{mL}$. The inter- and intraassay coefficients of variation were between 5.3 and $6.3 \%$ and between 3.4 and $8.0 \%$, respectively.

All samples from an individual subject were analyzed together.

The hormonal responses are expressed as absolute values. Spontaneous GH secretion was evaluated as mean GH concentration (mGHc) calculated as the mean of individual GH levels from 0 up to $300 \mathrm{~min}$.
The statistical analysis was carried out using nonparametric ANOVA (Wilcoxon ANOVA test or Mann-Whitney test, where appropriate).

The results are expressed as mean \pm SEM.

\section{Results}

Basal IGF-I levels in AN were lower than in NW (96.6 \pm 22.0 vs. $274.4 \pm 25.3 \mu \mathrm{g} / \mathrm{L}, P<0.01)$.

After placebo administration, the $\mathrm{mGHc}$, over $5 \mathrm{~h}$, was higher in AN than in NW (mGHc, $13.8 \pm 8.5$ vs.1.8 \pm 0.6 $\mu \mathrm{g} / \mathrm{L} ; P<0.01$ ). Similarly, the peak GH response to GHRH was higher in AN than in NW $(30.1 \pm 3.7$ vs. $20.6 \pm 2.9 \mu \mathrm{g} / \mathrm{L}$, $P<0.05)$

rhIGF-I administration increased circulating IGF-I levels in both groups (peak, $180.0 \pm 21.0 \mu \mathrm{g} / \mathrm{L}$ and $420.3 \pm 26.5$ $\mu \mathrm{g} / \mathrm{L}$ at $120 \mathrm{~min}$ in $\mathrm{AN}$ and $\mathrm{NW}$, respectively; $P<0.05$ ). rhIGF-I-induced IGF-I levels remained rather constant from $120 \mathrm{~min}$ up to $300 \mathrm{~min}$. The IGF-I percent increment was similar in the two groups (86\% and $77 \%$ in AN and NW), despite rhIGF-I having induced lower IGF-I levels in AN than in NW $(P<0.05)$ (Fig. 1)

rhIGF-I administration reduced $\mathrm{mGHc}$ in $\mathrm{AN}(6.8 \pm 3.2$ $\mu \mathrm{g} / \mathrm{L}, P<0.01)$ but not in NW $(1.6 \pm 0.3 \mu \mathrm{g} / \mathrm{L})$. Nevertheless, $\mathrm{mGHc}$ in AN, after rhIGF-I, persisted at a higher level than in NW $(P<0.05)$ (Fig. 1).

rhIGF-I administration inhibited the peak $\mathrm{GH}$ response to GHRH in AN $(21.3 \pm 4.1 \mu \mathrm{g} / \mathrm{L}, P<0.05)$, as well as in NW (13.1 $\pm 4.5 \mu \mathrm{g} / \mathrm{L}, P<0.05)$ (Fig. 2).

After rhIGF-I, the peak GH response to GHRH in AN persisted at a level higher than in NW $(P<0.01)$ but became similar to that recorded in NW after GHRH alone (Fig. 2).

Basal insulin $(7.3 \pm 2.5$ and $6.8 \pm 0.6 \mathrm{mU} / \mathrm{L}$ in $\mathrm{AN}$ and $\mathrm{NW})$ and glucose levels $(70.6 \pm 5.6$ and $74.9 \pm 5.7 \mathrm{mg} / \mathrm{dL}$ in $\mathrm{AN}$ and NW) were similar in both groups. After rhIGF-I, insulin levels showed a progressive decrease in $\mathrm{AN}(2.5 \pm 0.3 \mathrm{mU} / \mathrm{L}$ at $300 \mathrm{~min}, P<0.05)$ but not in NW $(5.3 \pm 0.1 \mathrm{mU} / \mathrm{L}$ at 300 min) (Fig. 1).

In contrast, glucose levels were unaffected by rhIGF-I in either group $(66.5 \pm 2.0$ and $73.9 \pm 3.7 \mathrm{mg} / \mathrm{dL}$ in $\mathrm{AN}$ and NW) (Fig. 1).

Basal IGFBP-1 levels in AN and NW were similar (70.9 \pm 10.9 and $56.6 \pm 7.8 \mu \mathrm{g} / \mathrm{L})$ and were increased $(P<0.05)$ by rhIGF-I administration in both groups (215.1 \pm 45.5 and

TABLE 1. Clinical and hormonal details of patients with anorexia nervosa

\begin{tabular}{|c|c|c|c|c|c|c|c|c|c|c|}
\hline $\begin{array}{c}\text { Case } \\
(\mathrm{n})\end{array}$ & Sex & $\begin{array}{l}\text { Age } \\
(\mathrm{yr})\end{array}$ & $\begin{array}{c}\text { BMI } \\
\left(\mathrm{kg} / \mathrm{m}^{2}\right)\end{array}$ & $\begin{array}{c}\text { Duration } \\
\text { of disease } \\
(\mathrm{yr})\end{array}$ & $\begin{array}{c}\text { FSH } \\
(\mathrm{U} / \mathrm{L})\end{array}$ & $\begin{array}{c}\mathrm{LH} \\
(\mathrm{U} / \mathrm{L})\end{array}$ & $\begin{array}{c}\mathrm{E} 2 \\
(\mathrm{nmol} / \mathrm{L})\end{array}$ & $\begin{array}{c}\text { FT3 } \\
(\mathrm{pmol} / \mathrm{L})\end{array}$ & $\begin{array}{c}\text { FT4 } \\
(\mathrm{pmol} / \mathrm{L})\end{array}$ & $\begin{array}{c}\text { TSH } \\
(\mathrm{mU} / \mathrm{L})\end{array}$ \\
\hline Case 1 & $\mathrm{~F}$ & 25 & 14.0 & 6.0 & 0.3 & 0.1 & 0.2 & 2.8 & 14.2 & 4.5 \\
\hline Case 2 & $\mathrm{~F}$ & 21 & 12.8 & 3.0 & 0.2 & 0.1 & 0.1 & 0.9 & 11.7 & 1.2 \\
\hline Case 3 & $\mathrm{~F}$ & 21 & 11.7 & 1.0 & 0.1 & 0.1 & 0.1 & 2.2 & 12.5 & 1.3 \\
\hline Case 4 & $\mathrm{~F}$ & 29 & 13.7 & 8.0 & 0.5 & 0.3 & 0.2 & 2.4 & 11.3 & 1.1 \\
\hline Case 5 & $\mathrm{~F}$ & 27 & 11.3 & 8.0 & 0.9 & 0.1 & 0.0 & 3.0 & 11.7 & 1.1 \\
\hline Case 6 & $\mathrm{~F}$ & 18 & 16.7 & 2.0 & 3.0 & 0.8 & 0.0 & 3.2 & 9.4 & 1.8 \\
\hline Case 7 & $\mathrm{~F}$ & 26 & 14.8 & 6.0 & 1.0 & 0.1 & 0.0 & 1.9 & 9.6 & 1.2 \\
\hline Case 8 & $\mathrm{~F}$ & 19 & 16.2 & 2.0 & 0.3 & 1.4 & 0.0 & 2.4 & 11.2 & 0.9 \\
\hline Case 9 & $\mathrm{~F}$ & 30 & 15.7 & 4.0 & 1.7 & 0.1 & 0.0 & 2.0 & 10.3 & 0.9 \\
\hline Mean & & 24.0 & 14.1 & 4.4 & 0.9 & 0.3 & 0.1 & 2.3 & 11.3 & 1.6 \\
\hline $\mathrm{SD}$ & & 1.5 & 0.6 & 0.9 & 0.3 & 0.2 & 0.0 & 0.2 & 0.5 & 0.4 \\
\hline SEM & & 1.4 & 0.6 & 0.8 & 0.3 & 0.1 & 0.0 & 0.2 & 0.5 & 0.4 \\
\hline
\end{tabular}

E2, Estradiol; FT3, free $\mathrm{T}_{3} ; \mathrm{FT} 4$, free $\mathrm{T}_{4} ; \mathrm{F}$, female. 

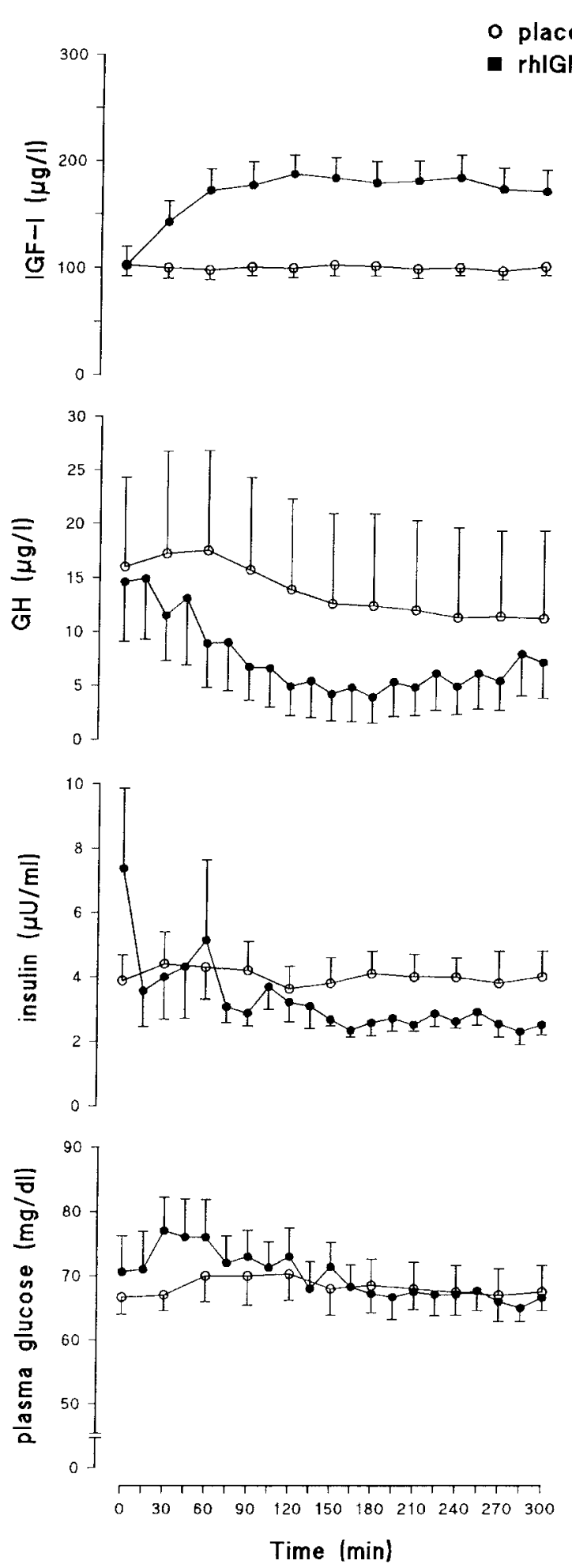

Fig. 1. Mean ( \pm SEM) serum IGF-I, GH, insulin, and plasma glucose levels after placebo or rhIGF-I ( $20 \mu \mathrm{g} / \mathrm{kg}$, sc at $0 \mathrm{~min})$ in patients with $\mathrm{AN}$ and in normal women.

$113 \pm 24.8 \mu \mathrm{g} / \mathrm{L}$ at $300 \mathrm{~min})$, though attaining higher levels in $\mathrm{AN}$ than in NW $(P<0.05)$.

Basal IGFBP-3 levels in AN were lower than in NW (3.6 \pm 0.5 vs. $6.6 \pm 0.5 \mu \mathrm{g} / \mathrm{L}, P<0.05)$ and were not modified after
rhIGF-I administration $(3.5 \pm 0.5$ and $6.9 \pm 1.1 \mu \mathrm{g} / \mathrm{L}$ in $\mathrm{AN}$ and NW).

\section{Side effects}

After rhIGF-I administration, some subjects in both groups experienced transient discomfort at the injection site, but no systemic side effects were observed. A transient facial flushing after GHRH administration was also experienced by most NW and by some AN patients.

\section{Discussion}

Our findings show that sc administration of a low rhIGF-I dose, which restored circulating IGF-I levels within the normal range, inhibited both spontaneous and GHRH-stimulated somatotroph secretion in patients with AN.

After rhIGF-I administration, the spontaneous GH secretion, though significantly reduced, persisted at a level higher than that in normal women, whereas the GH response to GHRH in anorectic patients overlapped that found after GHRH alone in controls.

In humans, the inhibitory effect of rhIGF-I on somatotroph hypersecretion has been shown in Laron's syndrome, IDDM, malnutrition, and fasting $(7,8,10,24,25)$. In healthy women, a low rhIGF-I dose inhibited the GHRH- and, more markedly, the GHRP-induced (but not the spontaneous) GH secretion (13). Thus, the inhibitory IGF-I-effect on somatotroph secretion is more evident in conditions of exaggerated $\mathrm{GH}$ secretion, peripheral GH insensitivity, and low IGF-I levels $(19,20,23,26)$. This proposition is consistent with our findings in anorectic patients; in fact, even a low IGF-I dose inhibited both spontaneous and stimulated GH secretion.

It is noteworthy, however, that in the anorectic patients of our study, after rhIGF-I, both spontaneous and stimulated GH secretion, though reduced, persisted at a level higher than in normal women.

The inability of rhIGF-I administration to normalize somatotroph secretion in $\mathrm{AN}$ is worth noting. In fact, hypersensitivity of IGF-I receptors in the median eminence during food restriction (32) might have enhanced the IGF-I feedback action in AN, a condition of GH resistance but IGF-I hypersensitivity (33).

However, it must be noted that circulating IGF-I levels, after rhIGF-I, in anorectic patients, though within the normal range, were lower than those in normal women. Moreover, in agreement with previous studies (34-36), we found that in anorectic (but not in normal) subjects, rhIGF-I inhibited insulin while increasing IGFBP-1 levels.

The rise in IGFBP-1 levels induced by hypoinsulinemia or the direct stimulatory effect of $\operatorname{rhIGF-I}(36,37)$ might reduce, in turn, the bioactivity of free IGF-I and, hence, its inhibitory feedback action, though coexistence of low IGFBP-3 levels should balance this change (38).

Thus, our findings do not allow the conclusion that the more marked GH secretion, the more marked the inhibitory effect of rhIGF-I; whereas they rather suggest that GH hypersecretion in AN does not simply reflect reduction of the negative IGF-I feedback action. In this context, the existence of a state of GH resistance is supported by the finding of a decreased circulating GH binding protein level in AN (19, 
Anorexia nervosa

Normal women

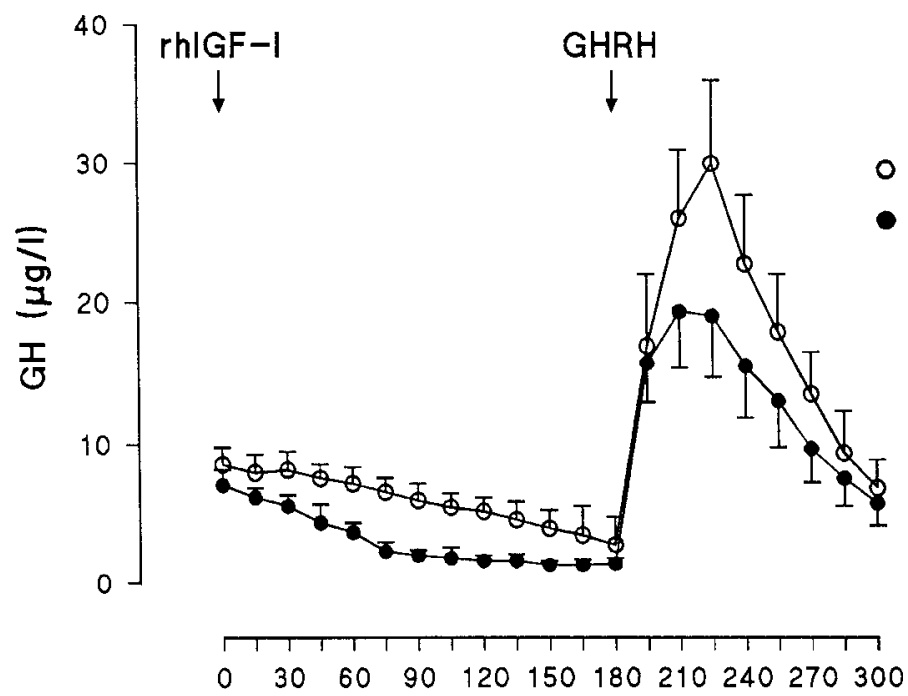

- GHRH

rhlGF-I+GHRH

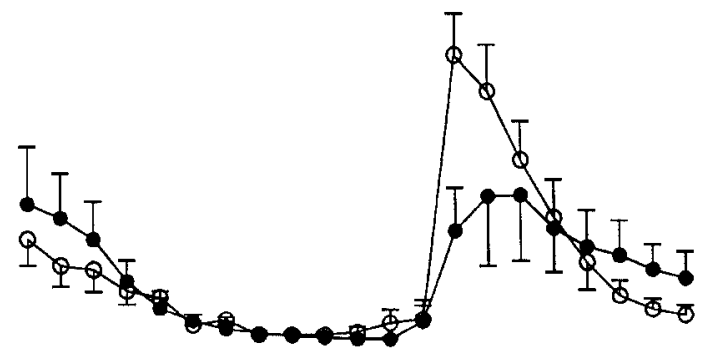

$030 \quad 60 \quad 90 \quad 120 \quad 150 \quad 180210240270300$

Time $(\min )$

FIG. 2. Mean ( \pm SEM) serum GH levels after GHRH (2 $\mu \mathrm{g} / \mathrm{kg}$, iv at $180 \mathrm{~min})$ alone or preceded by rhIGF-I ( $20 \mu \mathrm{g} / \mathrm{kg}$, sc at $0 \mathrm{~min})$ in patients with $\mathrm{AN}$ and in normal women.

33), because GH binding protein represents the extracellular domain of the $\mathrm{GH}$ receptor and is thought to reflect the $\mathrm{GH}$ sensitivity (39).

There is evidence that the enhanced somatotroph secretion in $\mathrm{AN}$ is the result of increased pulse frequency coupled with enhanced tonic GH release $(21,22)$. However, both the parameters of GH pulsatility and the magnitude of the GHRHinduced GH rise did not show any negative correlation with IGF-I levels $(21,22)$; this further suggests that factors other than, or in addition to, low IGF-I titers are responsible for the altered GH secretion in this disease (see below).

This contention by no means rules out the potential impact of malnutrition on the GH/IGF-I axis; in fact, besides reduction in circulating IGF-I levels, changes in IGFBPs and metabolic inputs could exert a critical role $(19,33,38,40,41)$.

It has to be pointed out, however, that in AN, primary alterations in the neuroendocrine control of somatotroph function have also been envisaged (17, 18, 21, 22, 26-28, 42, 43).

A primary hypothalamic GHRH hyperactivity, coupled with a low SRIF tone, has been proposed to explain GH hypersecretion $(17,18,21,22,26-28,42,43)$, though SRIF involvement has been questioned by other studies (44). An altered neurohormonal control of somatotroph function could, in turn, reflect changes occurring in the neurotransmitter control $(17,18,21,27,28,42,43)$.

In conclusion, this study shows that a low IGF-I dose inhibits, though does not normalize, spontaneous and stimulated GH secretion in AN.

These findings indicate that malnutrition-induced reduction of circulating IGF-I levels and its feedback action plays an important role in the enhanced GH secretion of these patients, though the existence of a hypothalamic dysregulation can not be ruled out.

\section{Acknowledgments}

We thank Drs. Josefina Ramunni, Maria Rosa Valetto, and M. G. Papini for their cooperation in the study; and Mrs. Marina Taliano for her skillful technical assistance.

\section{References}

1. Berelowitz M, Szabo M, Frohman LA, Firestone S, Hintz RL. 1981 Somatomedin- $C$ mediates growth hormone negative feedback by effects on both the hypothalamus and the pituitary. Science. 212:1279-1281.

2. Abe H, Molitch ME, Van Wyk JJ, Underwood LE. 1983 Human growth hormone and somatomedin C suppress the spontaneous release of growth hormone in unanesthetized rats. Endocrinology. 113:1319-1324.

3. Tannenbaum GS, Guyda HJ, Posner BI. 1983 Insulin-like growth factors: role in growth hormone negative feedback and body weight regulation via brain. Science. 220:77-79.

4. Yamashita S, Melmed S. 1986 Insulin-like growth factor I action on rat anterior pituitary cells: suppression of growth hormone secretion and messenger ribonucleic acid levels. Endocrinology. 118:176-182.

5. Ceda GP, Davis RG, Rosenfeld RG, Hoffman AR. 1987 The growth hormone (GH)-releasing hormone (GHRH)-GH-somatomedin axis: evidence for rapid inhibition of GHRH-elicited GH release by insulin-like growth factors I and II. Endocrinology. 120:1658-1662.

6. Guler HP, Schmid C, Zapf J, Froessch ER. 1989 Effect of recombinant insulinlike growth factor I on insulin secretion and renal function in normal human subjects. Proc Natl Acad Sci USA. 86:2868-2872.

7. Laron Z, Klinger B, Silbergeld A, Lewin R, Erster B, Gil-Ad I. 1990 Intravenous administration of recombinant IGF-I lowers serum GHRH and TSH. Acta Endocrinol (Copenh). 123:378-382.

8. Laron Z, Klinger B, Jensen LT, Erster B. 1991 Biochemical and hormonal changes induced by one week of administration of rhIGF-I to patients with Laron type dwarfism. Clin Endocrinol (Oxf). 35:145-150.

9. Spencer GSG, McDonald AA, Buttle HL, Moore LG, Carlyle SS. 1991 Intracerebral administration of insulin-like growth factor I decreases circulating growth hormone levels in the fetal pig. Acta Endocrinol (Copenh). 124:563-568

10. Hartman ML, Clayton PE, Johnson ML, et al. 1993 A low dose euglycemic infusion of recombinant human insulin-like growth factor I rapidly suppresses 
fasting-enhanced pulsatile growth hormone secretion in humans. J Clin Invest. 91:2453-2462.

11. Sato M, Frohman LA. 1993 Differential effects of central and peripheral administration of GH and insulin-like growth factor on hypothalamic GHreleasing hormone and somatostatin gene expression in $\mathrm{GH}$-deficient dwarf rats. Endocrinology. 133:793-799.

12. Fletcher TP, Thomas GB, Dunshea FR, Moore LG, Clarke IJ. 1995 IGF feedback effects on growth hormone secretion in ewes: evidence for action at the pituitary but not the hypothalamic level. J Endocrinol. 144:323-331.

13. Ghigo E, Gianotti L, Arvat E, et al. 1999 Effects of recombinant human insulin-like growth factor I administration on growth hormone $(\mathrm{GH})$ secretion, both spontaneous and stimulated by GH-releasing hormone or hexarelin, a peptidyl GH secretagogue, in humans. J Clin Endocrinol Metab. 84:285-290.

14. Frohman LA, Jansson JO. 1986 Growth hormone-releasing hormone. Endocr Rev. 7:223-231.

15. Shibasaki T, Yamauchi N, Hotta M, et al. 1986 In vitro release of growth hormone-releasing factor from rat hypothalamus: effect of insulin-like growth factor-I. Regul Pept. 15:47-51.

16. Harel Z, Tannembaum GS. 1992 Synergistic interaction between insulin-like growth factors I and II in central regulation of pulsatile growth hormone secretion. Endocrinology. 131:758-764.

17. Tamai HT, Komaki G, Matsubayashi S, et al, 1990 Effect of cholinergic muscarinic receptor blockade on human growth hormone $(\mathrm{GH})$-releasing hormone-(1-44)-induced-GH secretion in anorexia nervosa. J Clin Endocrinol Metab. 70:738-741.

18. Rolla M, Andreoni A, Belliti D, Cristofani R, Ferdeghini M, Müller EE. 1991 Blockade of cholinergic muscarinic receptors by pirenzepine and GHRHinduced GH secretion in the acute and recovery phase of anorexia nervosa and atypical eating disorders. Biol Psychiatry. 29:1079-1091.

19. Counts DR, Gwirtsman H, Carlsson LMS, et al. 1992 The effects of anorexia nervosa and refeeding on growth hormone-binding protein, the insulin-like growth factors (IGFs) and the IGF-binding proteins. J Clin Endocrinol Metab. 75:762-767.

20. Ross RJM, Chew SL. 1995 Acquired growth hormone resistance. Eur J Endocrinol. 132:655-660.

21. Scacchi M, Pincelli AI, Caumo A, et al. 1997 Spontaneous nocturnal growth hormone secretion in anorexia nervosa. J Clin Endocrinol Metab. 82:3225-3229.

22. Stoving RK, Veldhius JD, Flyvbjerg A, et al. 1999 Jointly amplified basal and pulsatile growth hormone $(\mathrm{GH})$ secretion and increased process irregularity in women with anorexia nervosa: indirect evidence for disruption of feedback regulation within $\mathrm{GH}$-insulin-like growth factor I axis. J Clin Endocrinol Metab. 84:2056-2063.

23. Donaghy AJ, Baxter RC. 1996 Insulin-like growth factor bioactivity and its modification in growth hormone resistant states. In: Ross RJM, Savage MO, eds. Bailliere's clinical endocrinology and metabolism. Vol 10. London: Balliere's Tindall; 421-446.

24. Vaccarello MA, Diamond FB, Guevara-Aguirre J, et al. 1993 Hormonal and metabolic effects and pharmacokinetics of recombinant insulin-like growth factor-I in growth hormone receptor deficiency/Laron syndrome. J Clin Endocrinol Metab. 77:273-280.

25. Cheetham TD, Connors M, Clayton K, Watts A, Dunger DB. 1997 The relationship between overnight GH levels and insulin concentrations in adolescents with insulin-dependent diabetes mellitus (IDDM) and the impact of recombinant human insulin-like growth factor-I (rhIGF-I). Clin Endocrinol Oxf). 46:415-424.

26. Dieguez C, Page MD, Scanlon MF. 1989 Growth hormone neuroregulation and its alterations in disease states. Clin Endocrinol (Oxf). 28:109-121.
27. Ghigo E, Arvat E, Gianotti L, et al. 1994 Arginine but not pyridostigmine, a cholinesterase inhibitor, enhances the GHRH-induced GH rise in patients with anorexia nervosa. Biol Psychiatry. 36:689-695.

28. Gianotti L, Arvat E, Valetto MR, et al. 1998 Effects of beta-adrenergic agonists and antagonists on the growth hormone response to growth hormone-releas ing hormone in anorexia nervosa. Biol Psychiatry. 43:181-187.

29. Ghigo E. 1992 Neurotransmitter control of growth hormone secretion. In: De La Cruz LF, ed. Regulation of growth hormone and somatic growth. Amsterdam: Elsevier Science Publishers; 103-136.

30. Müller EE, Locatelli V, Cocchi D. 1999 Neuroendocrine control of growth hormone secretion. Physiol Rev. 79:511-607.

31. American Psychiatry Association. 1987 Diagnostic and statistical manual of mental disorders. 3rd ed, revised. Washington DC: American Psychiatric Press, $1-958$.

32. Bohannon NJ, Figlewicz DP, Corp ES, Wilcox J, Porte D, Baskin DG. 1986 Identification of binding sites for an insulin-like growth factor (IGF-I) in the median eminence of the rat brain by quantitative autoradiography. Endocrinology. 119:943-945.

33. Hochberg Z, Hertz P, Colin V, et al. 1992 The distal axis of growth hormone $(\mathrm{GH})$ in nutritional disorders: GH-binding protein, insulin-like growth factor-I (IGF-I), and IGF-I receptors in obesity and anorexia nervosa. Metabolism. 41:106-112.

34. Young SC, Underwood LE, Celniker A, Clemmons DR. 1992 Effects of in sulin-like growth factor-I (IGF-I) and growth hormone on serum IGF-binding proteins in calorically restricted adults. J Clin Endocrinol Metab. 75:603:608.

35. Lieberman SA, Bukar J, Chen SA, et al 1992 Effects of recombinant human insulin-like growth factor-I (rhIGF-I) on total and free IGF-I concentrations, IGF-binding proteins, and glycemic response in humans. J Clin Endocrinol Metab. 75:30-36.

36. Lee PDK, Conover CA, Powell DR. 1993 Regulation and function of insulinlike growth factor-binding protein-1. Proc Soc Exp Biol Med. 204:4-29.

37. Conover CA, Lee PDK, Kanaley JA, Clarkson JT, Jensen MD. 1992 Insulin regulation of insulin-like growth factor binding protein-1 in obese and nonobese humans. J Clin Endocrinol Metab. 74:1355-1360.

38. Jones JI, Clemmons DR. 1995 Insulin-like growth factors and their binding proteins: biological actions. Endocr Rev. 16:3-34.

39. Herington AC, Ymer S, Stevenson J. 1986 Identification and characterization of specific binding proteins for growth hormone in normal sera. J Clin Invest. 77:1817-1823.

40. Argente J, Caballo N, Barrios V, et al. 1997 Multiple endocrine abnormalities of the growth hormone and insulin-like growth factor axis in patients with anorexia nervosa: effect of short- and long-term weight recuperation. J Clin Endocrinol Metab. 82:2084-2092.

41. Stoving RK, Flyvbjerg A, Frystyk J, et al. 1999 Low serum levels of free and total insulin-like growth factor-I (IGF-I) in patients with anorexia nervosa are not associated with increased IGF-binding protein-3 proteolysis. J Clin Endocrinol Metab. 84:1346-1350.

42. Masuda A, Shibasaki T, Hotta M, Suematsu H, Shizume K. 1988 Study on the mechanism of abnormal growth hormone $(\mathrm{GH})$ secretion in anorexia nervosa: no evidence of involvement of a low somatomedin-C level in the abnormal GH secretion. J Endocrinol Invest. 11:297-302.

43. Müller EE, Rolla M, Ghigo E, et al. 1995 Involvement of brain cathecolamines and acetylcholine in growth hormone hypersecretory states. Pathophysiological, diagnostic and therapeutic implications. Drugs. 50:805-837.

44. Gianotti L, Rolla M, Arvat E, et al. 1998 Effect of somatostatin infusion on the somatotrope responsiveness to growth hormone-releasing hormone in patients with anorexia nervosa. Biol Psychol. 45:334-339. 